\title{
INVESTIGATION OF FAILURES AND VERTICAL DISPLACEMENTS OCCURRING AT THE CHOREMI VILLAGE, NEAR THE MEGALOPOLIS' MINES
}

\author{
Avramidou E. ${ }^{1}$, Psychari E. ${ }^{1}$, Kanaris D. ${ }^{2,1}$, Tzampoglou P. ${ }^{1}$ and Loupasakis C. ${ }^{1}$ \\ ${ }^{1}$ National Technical University of Athens, School of Mining \& Metallurgical Engineering, 15780, \\ Athens, Greece,eftavramidou@hotmail.com,irene.psychari@hotmail.com, \\ dimitrios.kanaris@gmail.com,ploutarhos.21@hotmail.com,cloupasakis@metal.ntua.gr \\ ${ }^{2}$ Institute of Geology and Mineral Exploration, $1^{\text {st }}$ Spirou Louis St., Olympic Village, 13677, \\ Acharnae, Greece, dimitrios.kanaris@gmail.com
}

\begin{abstract}
The current study investigates the catastrophic phenomena affecting Choremi village, at the west boundaries of the Megalopolis' mines. For this purpose, field survey was carried out, failures in the houses were recorded, the level of aquifer was measured and soil samples were collected for the conduction of laboratory tests and mineralogy analysis. The conclusions of the investigation were verified by slope stability analysis. By evaluating all available data, it is clear that the displacements damaging the village occur due to slope failure and swelling of the clay formations of the narrow study area.
\end{abstract}

Keywords: slope failures, swelling, swelling potential.

\section{Пєрі́⿱亠乂 $\psi \eta$}

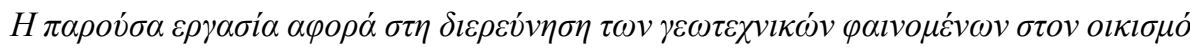

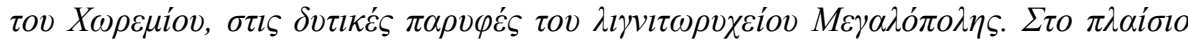

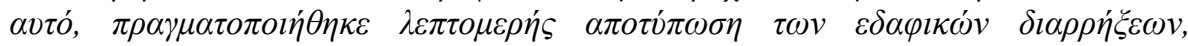

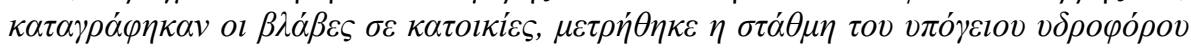

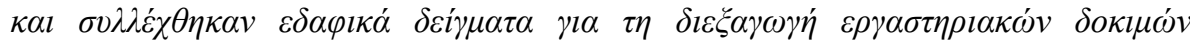

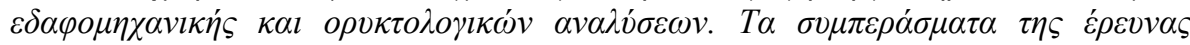

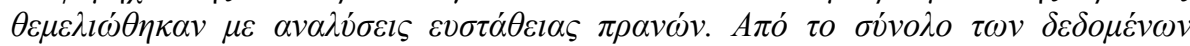

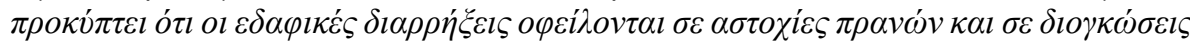

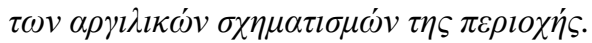

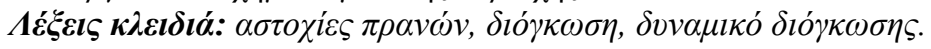

\section{Introduction}

Landslides occurrence depends on multiple interrelated factors, such as the geological environment, the geomorphological characteristics, the seismicity, the geotechnical characteristics of the geological formations and the effects of anthropogenic interventions over the landscape.

The current study investigates the catastrophic phenomena affecting the Choremi village, located at the western boundaries of Megalopolis coal mines. Those phenomena, recorded as subsidence vertical deformations, affect the area since 1998 and causing numerous damages to the constructions. The study was conducted by evaluating field survey data, ground water level measurements, 
laboratory tests and mineralogy analysis. Moreover, the laboratory tests on numerous samples permitted the investigation of the relation between the swelling capacity of clays and their physicalmechanical properties.

\section{The Study Area}

The municipal district of Choremi belongs to the municipality of Megalopolis, central Peloponnese. The village is located about $5 \mathrm{~km}$ SW of Megalopolis, $200 \mathrm{~m}$ west of the new riverbed diversion Alpheus and 700m west of the mine Megalopolis (Figure 1).

Choremi is developed in a hilly area surrounded by smooth $\left(5-10^{\circ}\right)$, to local moderately smooth slopes. The absolute elevation of the area ranges from 370 to 390 meters.

The geological formations constituting the wider area are of Pleistocene age and belong to the homonymous Choremi Formations. They are $200 \mathrm{~m}$ in thickness including the Marathousa and the Megalopolis formation. The settlement is founded over the Marathousa formations, constituted by alternations of marls, clays, humus clays and lignite layers, with interference of sands and loose conglomerates. The groundwater level underneath the village is located at an average depth of $8 \mathrm{~m}$.

The narrow study area is intersected by numerous fractures located both on the slopes surrounding the settlement and the flat hilltop hosting the village. During the autopsy there were recorded failures in both buildings and in lightweight constructions like stockyards, warehouses etc. (Figure 2-B). Along the slopes, the fractures and the displacements were attributed to rotational and planar slides, as well as to creep movements of the shallow weathering mantle of formations. Failures documented at a distance from the slopes cannot be attributed to landslide phenomena.

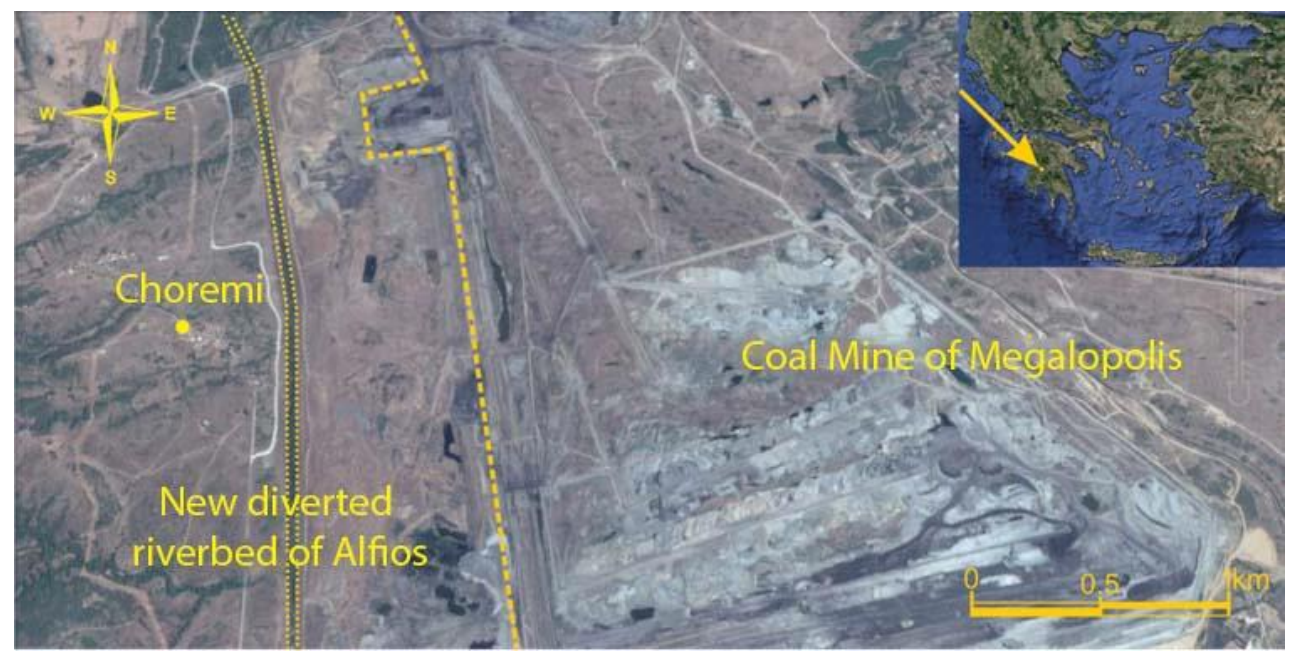

Figure 1 - Satellite image (Google Earth) presenting the location of Choremi village, the new diverted riverbed of Alfios river and the boundaries of the Megalopolis coal mine. 


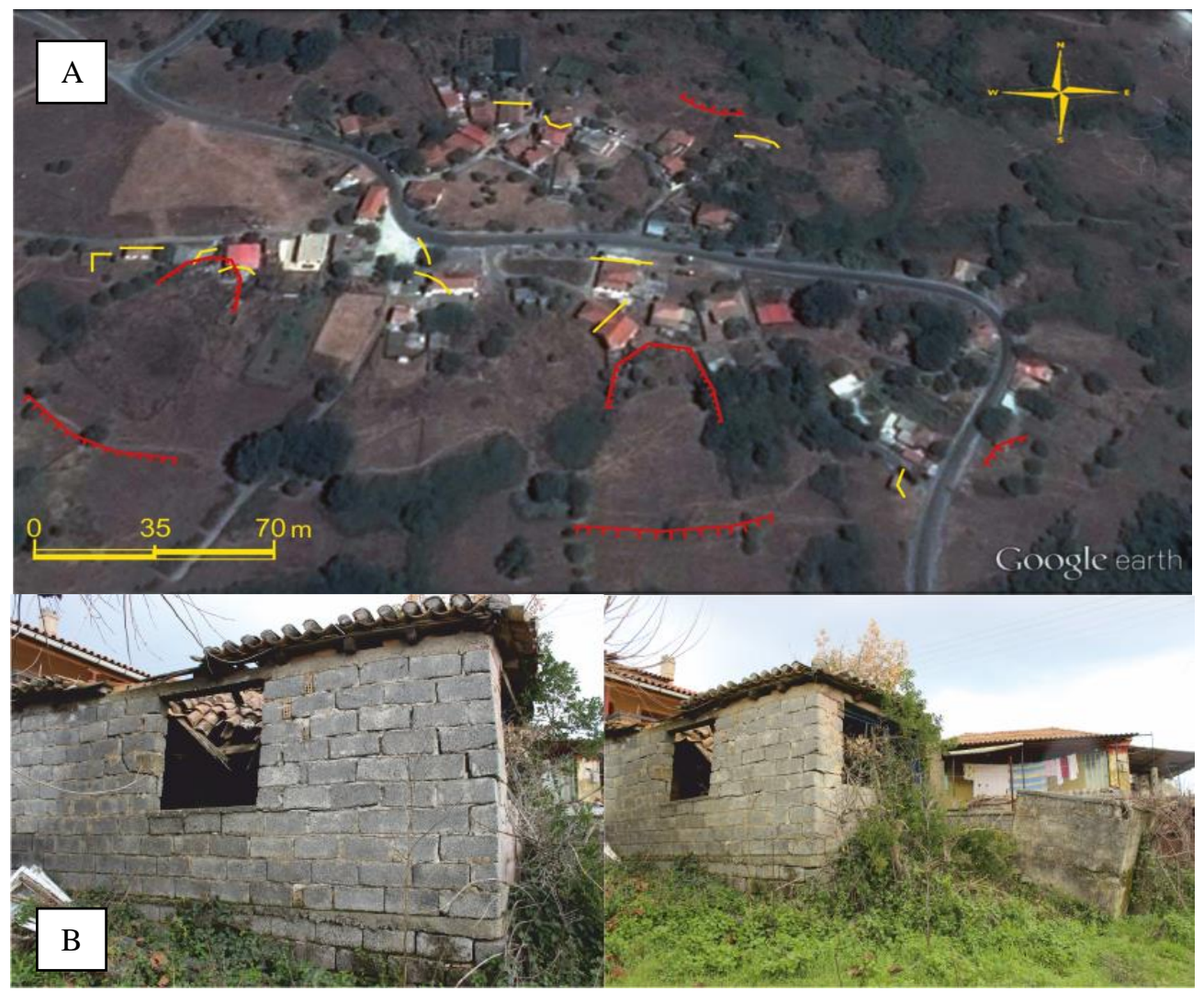

Figure 2 - A) The distribution of the failures. Slope failures are marked red, while failures in structures are marked yellow. B) Damaged buildings across the village.

\section{Geotechnical Properties of the Foundation Formations}

The physical-mechanical properties of the formation formations of the village were determined by conducting laboratory tests in soil samples collected during the present investigation $(\Delta 1, \Delta 2$ and $\Delta 3)$. Data from studies in the region, that had been carried out in the past, by Nikolaou et al. (2010) and Kynigalaki et al. (2010), were also available. The sampling locations of all samples evaluated, are presented in Figure 3, while the main mechanical parameters are presented in Table 1.

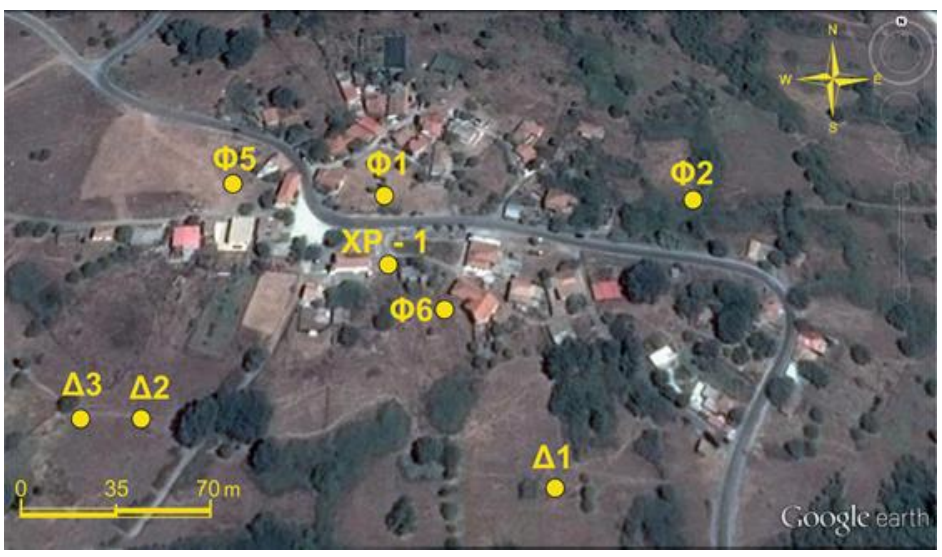

Figure 3 - Sampling locations. 
Table 1 - Physical and Mechanical properties of the soil materials.

\begin{tabular}{|c|c|c|c|c|c|c|c|c|c|c|c|c|c|}
\hline 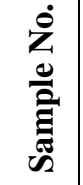 & 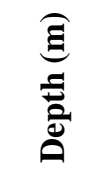 & $\underbrace{20}_{\frac{\pi}{0}}$ & 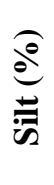 & 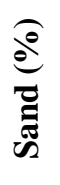 & $\frac{\sqrt{2}}{\sqrt[8]{0}}$ & $\underbrace{a}$ & $\underbrace{2}_{a}$ & $\underbrace{2}$ & 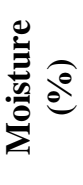 & $\bigcup_{\mathscr{W}}^{\mathscr{D}}$ & 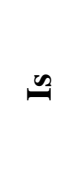 & 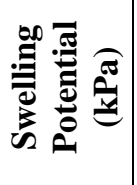 & $\varangle$ \\
\hline XP-1 & $\begin{array}{c}1,80- \\
2,10\end{array}$ & 75 & 25 & 0 & 0 & 69,5 & 23,9 & 45,6 & 24,2 & $\mathrm{CH}$ & 0,35 & $50-100$ & 0,65 \\
\hline XP-1 & $\begin{array}{c}5,60- \\
5,85 \\
\end{array}$ & 52 & 35 & 5 & 8 & 46,0 & 16,9 & 29,1 & 24,6 & CL & 0,53 & $50-100$ & 0,62 \\
\hline XP-1 & $\begin{array}{c}11,20- \\
11,70\end{array}$ & 43 & 52 & 2 & 3 & 40,2 & 15,9 & 24,3 & 16,7 & CL & 0,42 & $25-50$ & 0,64 \\
\hline XP-1 & $\begin{array}{c}17,00- \\
17,50\end{array}$ & 61 & 36 & 3 & 0 & 32,7 & 18,8 & 13,9 & 16,6 & CL & 0,51 & $50-100$ & 0,25 \\
\hline$\Phi-1$ & 2,00 & 76 & 21 & 3 & 0 & 70,5 & 32,4 & 38,1 & 32,7 & $\mathrm{CH}$ & 0,46 & $50-100$ & 0,54 \\
\hline$\Phi-2$ & 0,70 & 24 & 58 & 18 & 0 & 35,5 & 17,3 & 18,2 & 15,0 & CL & 0,42 & $50-100$ & 0,96 \\
\hline$\Phi-5$ & 1,50 & 50 & 49 & 1 & 0 & 71,3 & 31,6 & 39,7 & 36,1 & $\mathrm{CH}$ & 0,51 & $50-100$ & 0,88 \\
\hline$\Phi-6$ & 1,00 & 75 & 23 & 2 & 0 & 74,3 & 37,9 & 36,4 & 32,1 & $\mathrm{CH}$ & 0,43 & $200-400$ & 0,52 \\
\hline$\Delta-1$ & SS* & 25 & 37 & 38 & 0 & 37,0 & 20,3 & 16,8 & 21,6 & CL & 0,58 & $25-50$ & 0,84 \\
\hline$\Delta-2$ & $\mathrm{SS}^{*}$ & 27 & 28 & 43 & 2 & 38,0 & 22,0 & 16,0 & 22,7 & $\mathrm{CL}$ & 0,60 & $25-50$ & 0,73 \\
\hline$\Delta-3$ & SS* & 33 & 37 & 30 & 0 & 45,0 & 27,2 & 17,8 & 23,1 & ML & 0,51 & $25-50$ & 0,64 \\
\hline
\end{tabular}

* Surface Sampling

Table 2 - Estimated swelling potential values. Number of samples per swelling potential cate gory.

\begin{tabular}{|l|l|l|l|l|l|}
\hline $\begin{array}{c}\text { Estimation Of } \\
\text { Swelling } \\
\text { Potential }\end{array}$ & $\begin{array}{c}\text { Seed } \\
\text { et al, } \\
\mathbf{1 9 6 2}\end{array}$ & $\begin{array}{c}\text { Van der Merwe } \\
\text { modified by } \\
\text { Grabowska } \\
\text { Olszewska, 1998 }\end{array}$ & Chen, 1988 & $\begin{array}{c}\text { Casagrande } \\
\text { modified by } \\
\text { Grabowska- } \\
\text { Olszewska, 1998 }\end{array}$ & $\begin{array}{c}\text { Swelling } \\
\text { Test }\end{array}$ \\
\hline Low & 0 & 1 & 1 & 1 & 4 \\
\hline Medium & 4 & 5 & 7 & 6 & 6 \\
\hline High & 4 & 1 & 6 & 1 & 1 \\
\hline Very high & 3 & 4 & 4 & 3 & \\
\hline
\end{tabular}



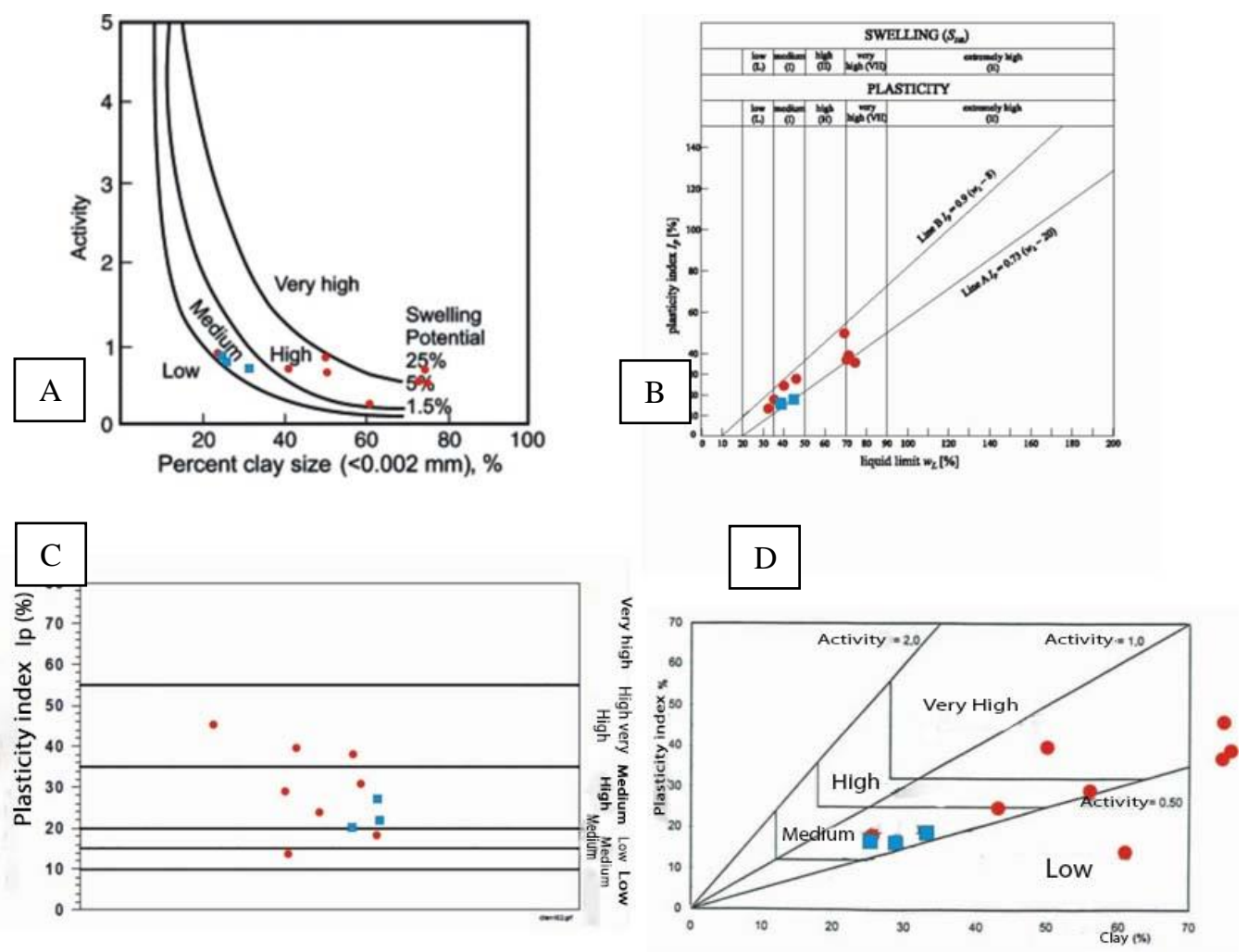

Figure 4 - Determination of the swelling potential of the soil formations according to A) Seed et al., 1962 B) Casagrande diagram modified by Grabowska - Olszewska, 1998, C) Chen, 1988 and D) Van der Merwe, 1964 modified by Grabowska - Olszewska, 1998.

Due to the fact that many of the failures affecting the flat hilltop are located at a distance from the slopes and in places that no loads by constructions are applied, it was considered appropriate to investigate the swelling potential of the foundation formations.

Determination of the swelling potential of soils was carried out according to a) Seed et al., 1962 (Figure 4-A) b) Casagrande diagram modified by Grabowska - Olszewska, 1998 (Figure 4-B) c) Chen, 1988 (Figure 4-C) d) Van der Merwe, 1964 modified by Grabowska - Olszewska, 1998 (Figure 4-d). The results are summarized in Tables 2.

Based on the estimations (Table 2) and the laboratory tests regarding the swelling potential values the majority of the samples present medium to high values, justifying the occurrence of failures even in locations subjected in very low surface loading.

\section{Slope Stability Analysis}

For the estimation of the slopes' stability, repeated analyses were conducted using the Larix-5 software. For that purpose the geological formations were grouped in three horizons based on their geotechnical characteristics (Figure 5). The surface horizon consists of yellowish brown, high plasticity clay of $2 \mathrm{~m}$ thickness, extending along the hilltop. The underlying horizon consists of brown medium plasticity clay, extending down to the depth of $13 \mathrm{~m}$, occupying the main part of the slope. The lower horizon consists of black clay.

The stability analyzes were conducted considering that the ground water level is located at depths varying from 2 to $6 \mathrm{~m}$. During the analyses, external loads applied by buildings were also taken into account. Seismic loading of the slopes were also applied, taking into consideration that according to 
the Greek Seismic Code (2000), the region is classified to the second seismic hazard zone with the maximum ground acceleration being $\mathrm{a}=0.24 \mathrm{~g}$.

The stability analyses were conducted by using the Krey and the Janbu's limit equilibrium methods. The results of the simulations indicated that several sections of the slopes surrounding the settlement are in limit equilibrium conditions (Figure 5).

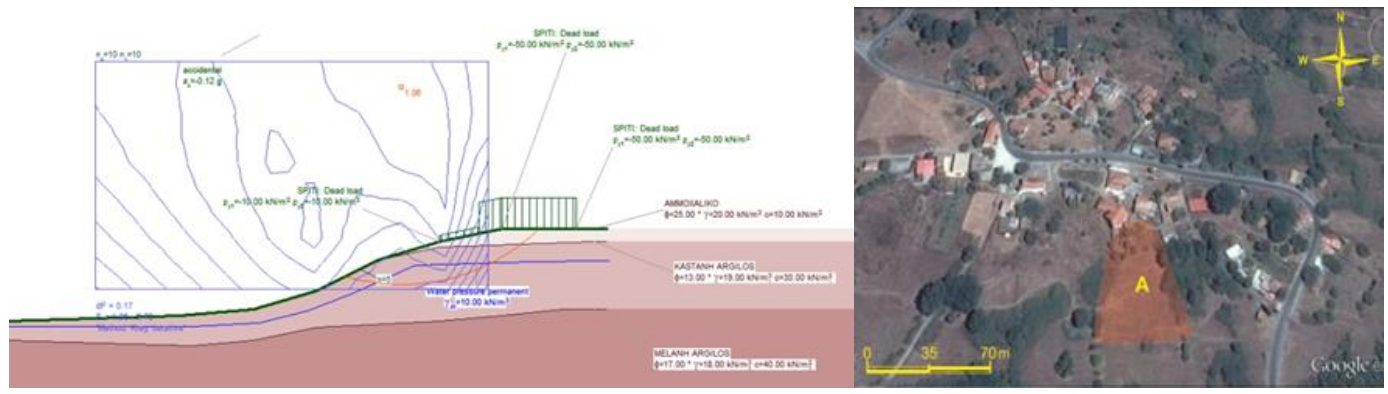

Figure 5 - Indicative slope stability analysis at the location A.

\section{Conclusions}

Summarizing the geotechnical investigation proved that the raptures and the movements recorded at the narrow Choremi village region, are due to rotational slides and creep movements affecting the slopes. Furthermore, failures occurring at the flat hilltop can be safely attributed to swelling phenomena. This fact is supported by the fact that the formations present high swelling potential.

\section{References}

Koudoumakis, P., Papakyriakopoylos, P. and Xidakis, G., 2006. Estimate of Swelling Potential of Soils with Empirical Systems application in the Soils of the Egnatia Highway in the Region of Thrace, $5^{\text {th }}$ Pan-Hellenic conference of Geotechnical and Geoenvironmental Engineering, Xanti.

Kynigalaki, M., Kanaris, D., Nikolaou, N. and Kontogianni, V., 2010. Buildings' damage at Horemi village, Arkadia, Greece. Proceedings 12th International Congress, Planet Earth: Geological Processes \& Sustainable Development, Bulletin of the Geological Society of Greece, XLIII (3), 1202-1209.

Nikolaou, N., Kynigalaki, M. and Kanaris, D., 2008. Engineering geological investigation at the Choremi district, Megalopoly Municipality, Arkadias County, unpublished report IGME.

Pajak-Komorowska, A., 2003. Swelling, expansion and shrinkage properties of selected clays in the Mazowsze province, central Poland, Geol. Quart., 47(1), 55-62, Warszawa. 


\title{
GEOLOGICAL 3D MODELING OF THE COPPER ORE MINERALIZATION AT KCIRA, ALBANIA
}

\author{
Bele S. ${ }^{1}$ and Bele M. ${ }^{2}$ \\ ${ }^{1}$ Polytechnic University of Tirana, Geological Faculty of Mining, Geoinformation Department, \\ Tirana, Albania,bele.s@hotmail.com \\ ${ }^{2}$ Albanian Geological Survey, Tirana, Albania,meglibele@gmail.com
}

\begin{abstract}
Albania despite its small territorial area is rich in mineral deposits whether they are us able or not. One of these deposits which is the source of copper ore ocurs in Kçira. The Kçira copper mine is located about $12 \mathrm{~km}$ to the west of the town of Puka, in Albania. Due to the rapid technological change it is easier to process data and create a $3 D \mathrm{~m}$ odel of the mineral body, also increasing the accuracy of calculating the amount of mineral containment of the mineral source. This article treats the 3D modeling of the copper ore using the softwares ArcMap 10.3 and Mircomine.

This model serves in reduce the time and cost for research and exploitation by facilitati $n g$ the work of geologists, institutions and companies for their respective functions.

Geological modeling is a recent sub-discipline of geology which integrates structura l geology, sedimentology, paleoclimatology and diagenesis.

The model that we obtain for this source is important because it allows us to calculat $e$ the amount of copper reserves, the amount of reserves used and the remainingamo unt in the source.

Keywords: Reserves, Puka, Micromine.
\end{abstract}

\section{Introduction}

To judge the mineral potential of a region selected from the mining company to search for minerals it is necessary to implement a research project. This project consists of several successive phases and the implementation of each phase depends on the positive results obtained. Mineral deposits research aims in finding a mineral source and the process consists of several stages. Before we conduct the search for a mineral we must know very well the geological aspect of the region under study based on the data we have for it. Obtaining these data (mainly by drilling) of a perspective area, a deep knowledge of several factors are required because this process has monetary costs and lasts much time.

In recent years in response to growing demand for minerals and the difficulties of finding new deposits, innovative technologies have been developed to help geologists for exploration in regions where minerals do not appear on the surface.

These large investments engage geologists to make predictions for unknown mineral deposits beneath the surface of the Earth. Exploration and search of mineral deposits is probably one of the most dangerous financial enterprises based on the complexity of nature and the fact that the concentrations of metals in the form of a source are quite rare on Earth. 
Despite the fact that a region can have the geological premises for mineral potential, its value cannot be determined until the evidence is obtained through a process called "drilling" that enables the evaluation of the mineral content in 3 dimensions. The presentis contribution analyzes and processes the geological data for the Kcira ore mineralization by creating a 3 dimensional model using the ArcMAp and Micromine programs.

Geological modeling or geomodeling is the science of creating a computer representation of a portion the Earth's crust based on geophysical and geological observations made on and below the surface of the Earth.

\section{Description of the study area}

The studied area is located about $12 \mathrm{~km}$ to the west of the town of Puka, in Albania. The origin of Kcirës included in scale measurement and topographic surveying 1-25 000 with the nomenclature K-34-064-D-c (Figure 1).

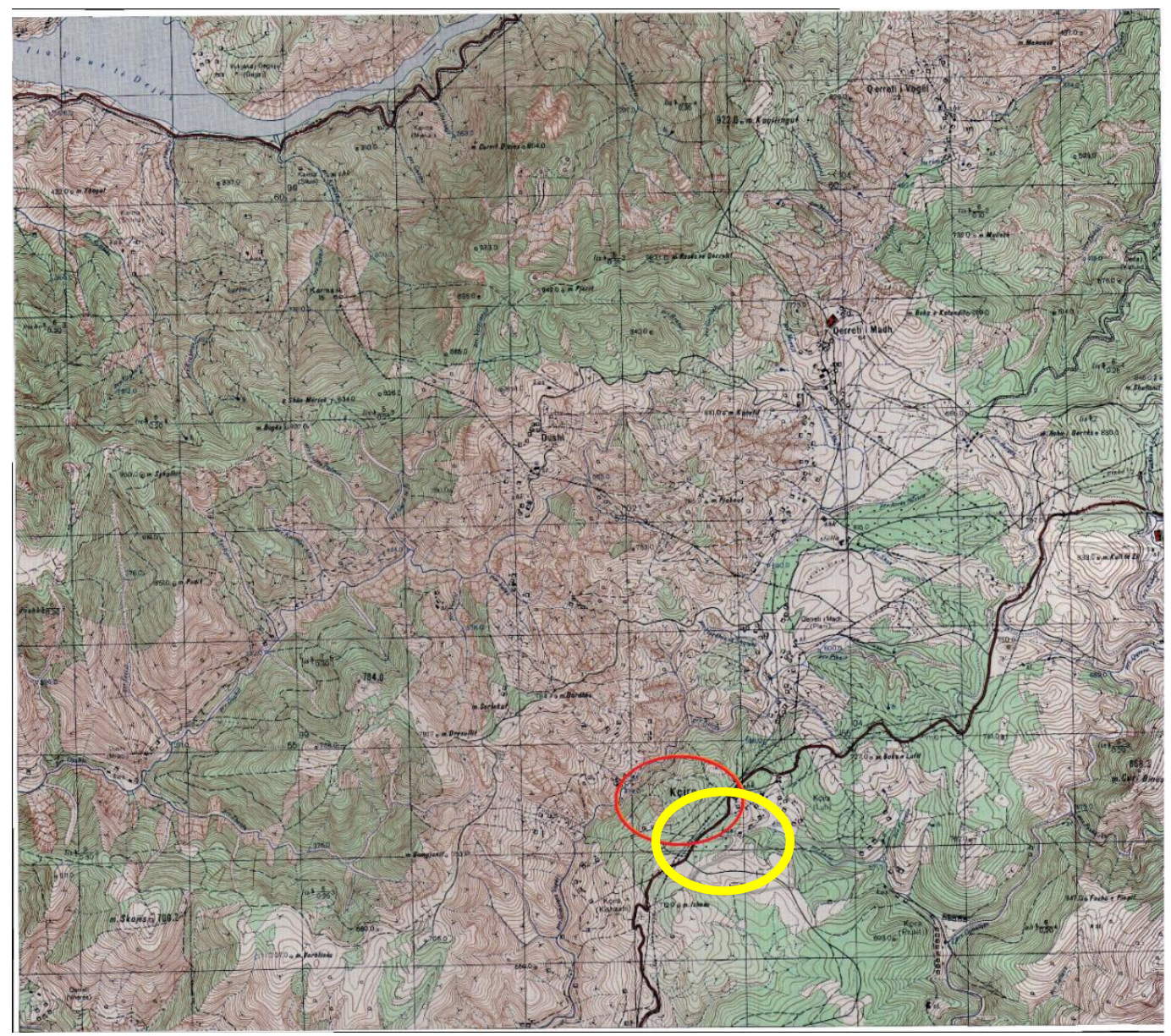

Figure 1 - Topographic map.

The mining area has hilly morphological characteristics with, an average height at about $620 \mathrm{~m}$, ranging between $390 \mathrm{~m}$ and $704.2 \mathrm{~m}$, at Peak Lepurthit.

The hydrographic network is represented by a main stream, the Shise river, which crosses the area from Northeast-Southwest. 
The region is characterized by a mountain continental climate with cool summers and harsh winters. Minimal temperature is $-15^{\circ} \mathrm{C}$ and maximal is $32^{\circ} \mathrm{C}$.

The region of Kcira has a complicated geological construction conditioned by the diversity of rocks and the development of powerful secessionist tectonics. The Kcira ore mineralization is concentrated in the gabbro of Kcira, consisting primarily of altered normal leukokrate. This massif has a length of $40 \mathrm{~km}$.

\subsection{Main rock types}

- Gabbro is the most widespread rock type in the region represented by leukokrate. These kinds of gabbro are encountered throughout the cross section of the massif.

- Gabbro diabases -which are constantly encountered in the area, are a structural variety of normal gabbro mentioned above. They are characterized by the gabbro ophiolite construction.

- Gabbronorites -are found in loose form on the surface in the northern and southern part of the area. These are known for restraint, alongside plagioclases and of pyroxene.

- Olivine gabbros are distinguished by the presence of olivine in addition to basic plagioclases and pyroxenes.

\subsection{Mineral composition of ore types}

Concernig the mineral composition we distinguish these types of ore mineralization:

- The copper chlorine-sulphide type is found at the northern area and is represented by ore veins in 10-140ml stretch. From the microscopic study of this type the following metallic mineral composition results:

(1) chalcopyrite $15.2 \%$

(2) pyrite $0.11 \%$,

(3) iron hydroxides up to $0.04 \%$

- The quartz sulphurtype is located at the southern part of the northern area. From the macroscopic description of the drilling samples the main metallic minerals are chalcopyrite, azurite, iron hydroxides.

- The simple type of copper sulphide is represented by veins that fill the cracks of almost fresh gabbro. It has a mineral composition of chalcopyrite, pyrite and iron hydroxides.

\subsection{Tectonics of study area}

The minig area characterized by local and regional tectonic faults. The Kcira region is part of the tectonic area of Mirdita.

\subsection{Hydrological conditions}

Based on hydrogeological studies the Kcira ore district according to the longitudinal direction can be divided into two parts, where the eastern side is liquefied, while in the western part water has negligible values or is absent.

The existence of numerous cracks cause the groundwater to be present uniformly throughout the eastern side with a thickness of 50-60 m from the ground surface.

The groundwater originates only from atmospheric precipitation directly from the soil surface through cracks.

Taking into account the hypsometric position of the source, as well as the geological construct with small cracks that close at depth and feed only from atmospheric precipitation, it is concluded that the mining area has simple hydrological conditions. 


\section{Methodology}

The methodology used is the combination of two programs, ArcMap and Micromine, using data from the drills done in the area and all the graphic material for this area.

These programs were used for the different characteristics that they are provided during for geological mapping. The attributes of the ArcMap program were used for the digitalization the geological map scale 1: 2000 for the source of Kcira with all its layers such as topography, hydrography, drilling, etc. These layers were then used in the Micromine program to reconcile the quota done in the tables generated by the geological drilling columns to the location of these drillings in the digitized map, referring to mapping of geological contours. In a way ArcMap helped to control data input in Micromine and their correction in case of any possible error to increase the accuracy of product output in our case 3D model of the copper ore body.
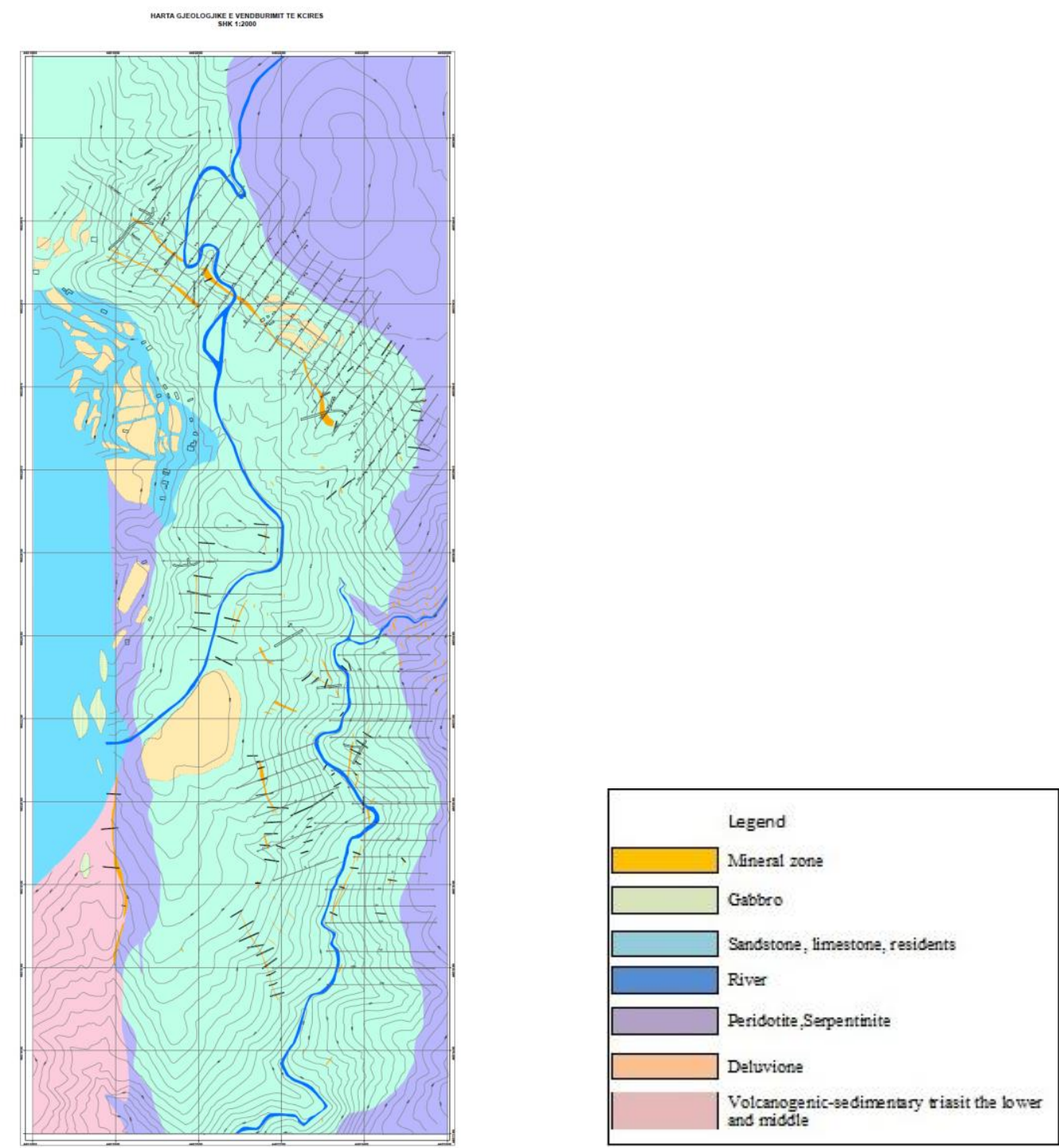

Figure 2 - Geological map, scale 1:2000. 
Micromine software was used to generate the 3D model by building the 4 base tables with which it works. (Collar, Survey, Litology). The data cast in these tables were taken from the data of the 88 drillings carried out in the area. The above mentioned tables are as follows:

Table 1 - COLLAR with its 5 fields.

\begin{tabular}{|c|c|c|c|c|}
\hline Dhole & $\mathbf{Y}$ & $\mathbf{X}$ & $\mathbf{Z}$ & Actual depth (ml) \\
\hline 1 & 4653310.850 & 4402031.430 & 619.48 & 105.2 \\
\hline 4 & 4653221.150 & 4402121.500 & 627.62 & 103.6 \\
\hline 6 & 4652950.360 & 4402311.760 & 620.24 & 100.3 \\
\hline
\end{tabular}

Dhole are number of drilling, $\mathrm{y}, \mathrm{x}, \mathrm{z}$ coordinates and drilling depth in $\mathrm{ml}$.

Construction of the tables we see that Exel drilling quotes ranging from $600-650 \mathrm{~m}$.

Table 2 - Analysis with all its fields.

\begin{tabular}{|l|l|l|l|l|l|l|l|l|}
\hline Dhole & \multicolumn{1}{|c|}{ Sample } & From & \multicolumn{1}{|c|}{ To } & $\operatorname{Rp}(\mathrm{m})$ & $\mathrm{Cu}(\%)$ & $\operatorname{Co}(\%)$ & $\mathrm{S}(\%)$ & $\mathrm{Zn}(\%)$ \\
\hline 1 & 2592 & 81.4 & 88.2 & 0.80 & 0.11 & 0.02 & & - \\
\hline 1 & 2598 & 38.5 & 39 & 0.50 & 0.22 & 0.006 & & - \\
\hline 1 & 2525 & 12.1 & 13.1 & 1.00 & 1.61 & 0.0025 & 104 & - \\
\hline
\end{tabular}

The following table presents data analysis of the results of the analysis, considered the number of drilling, the depth, elements such as $\mathrm{Cu}, \mathrm{S}, \mathrm{Co}, \mathrm{Zn}$, etc.

Table 3 - Lithology with all the fields.

\begin{tabular}{|l|l|l|l|l|l|l|l|}
\hline Dhole & From & \multicolumn{1}{|c|}{ To } & Code & Tdepth & Clorite & Calcopirite & Sulphur \\
\hline 1 & 0 & 1 & DEV & 1 & & & \\
\hline 1 & 1 & 11 & GAB & 10 & & & S \\
\hline 1 & 11 & 14 & ZON & 3.4 & K & & \\
\hline
\end{tabular}

Here Presented data coordinates, X, Y, Z and depth of drilling.

Table 4 - Survey with all the fields.

\begin{tabular}{|l|c|l|l|l|l|l|}
\hline Dhole & East & North & RI & Tdepth & Azimute $\left({ }^{\circ}\right)$ & $\begin{array}{c}\text { Zenith } \\
\text { angle }\left({ }^{\circ}\right)\end{array}$ \\
\hline 1 & 4653310.850 & 4402031.430 & 619.48 & 105.2 & 35 & -80 \\
\hline 4 & 4653221.150 & 4402121.500 & 627.62 & 103.6 & 35 & -80 \\
\hline 6 & 4652950.360 & 4402311.760 & 620.24 & 100.3 & 35 & -80 \\
\hline
\end{tabular}

Here Including coordinates, quotes, Azimuth.

Drilling are performed by moving the surface angles of $70-90^{\circ}$ (Most are performed with angle $80^{\circ}$ ). Deep drilling have described all of the mineralized zone. The average depth of drilling has been 100$140 \mathrm{ml}$. 
After building the tables and importing the shape files built in ArcMap, the 3D model was generated in Micromine.

\section{Results}

Figure 3 shows the 3D landscape together with drillings of the Kcira region, giving a clear idea of the number of drillings, their quota and spread.

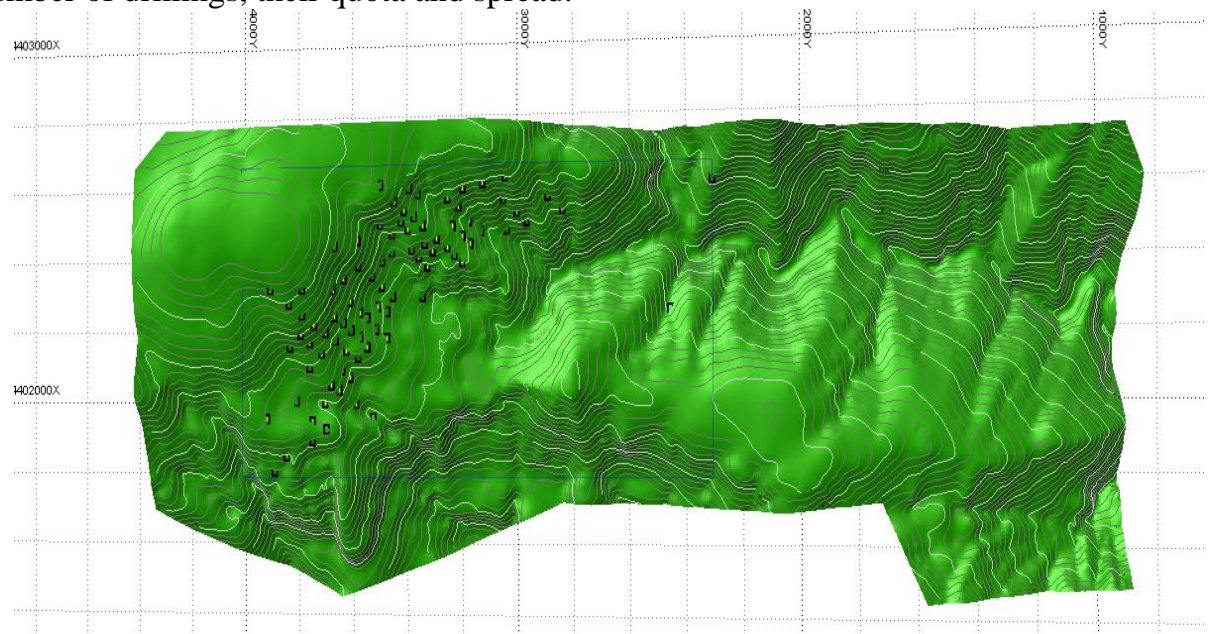

Figure 3 - The landscape of the area together with drilling.

Figure 4 shows the 3D model of the copper ore body seen from underneath along with the earth's surface. It also shows the drillings, reflecting the angle of the drill and their depth, which as is shown are different.

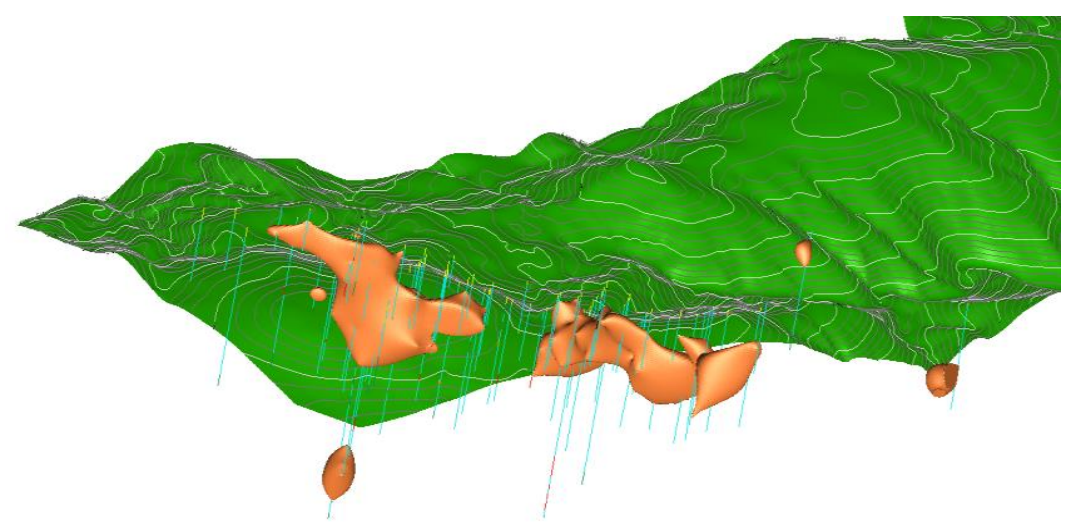

Figure 4 - The mineral model seen from underneath.

Figure 5 presents the model of the first area from above, undressed from the cover of the earth, along with the drills and the preliminary number of the drills that enables us to also controll for the accuracy of the generated model by referring to the number of the drill. 


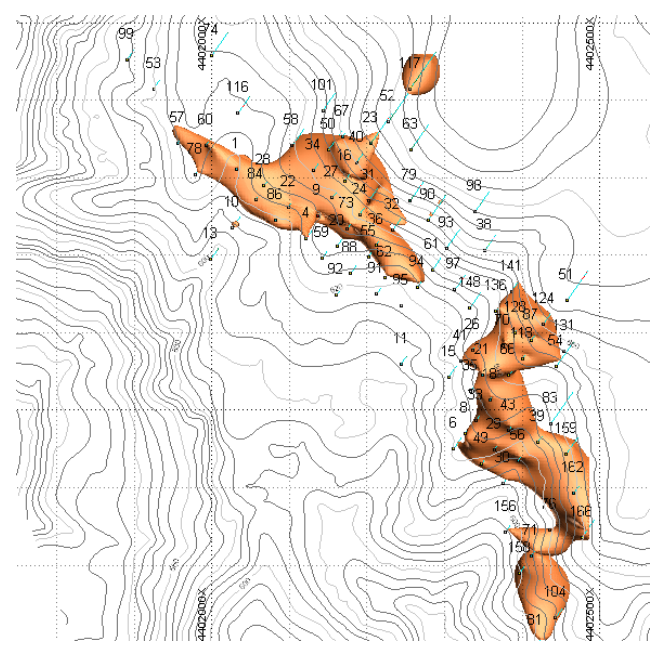

Figure 5 - The model of the mineral area seen from above.

Figure 6 shows the copper ore body through various blocks with different copper content in order to enable a clearer presentation of the spread of the body and its characteristics.
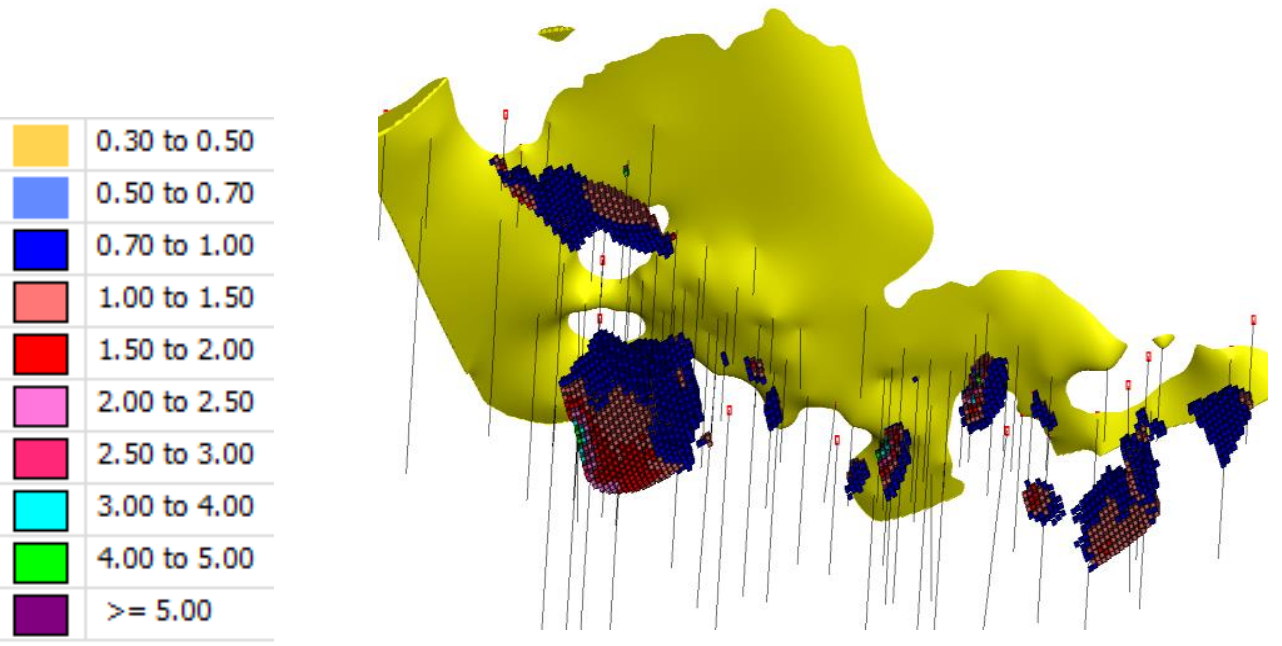

Figure 6 - Presentation of the ore body with blocks.

Figure 7 is the appearance of a longitudinal cut, as through micromine the mineral body can be cut anywhere on the basis of the needs of user, to create clear ideas on the shape, spread, \% of ore found, etc.

\subsection{Conclusions}

The source is concentrated on the gabbro massif of Kcira, which is bordered on the east by the ultrabasic rocks and cliffs in the west of volcanogenic-sedimentary.

The gabbro massif of Kcira has a prolonged irregular shape and tectonic borders with the side rocks.

The petrographic composition of this gabbro massif is mainly made of leukokrates, gabbro and to a lesser extent gabbro diabases, gabbronorites etc. 


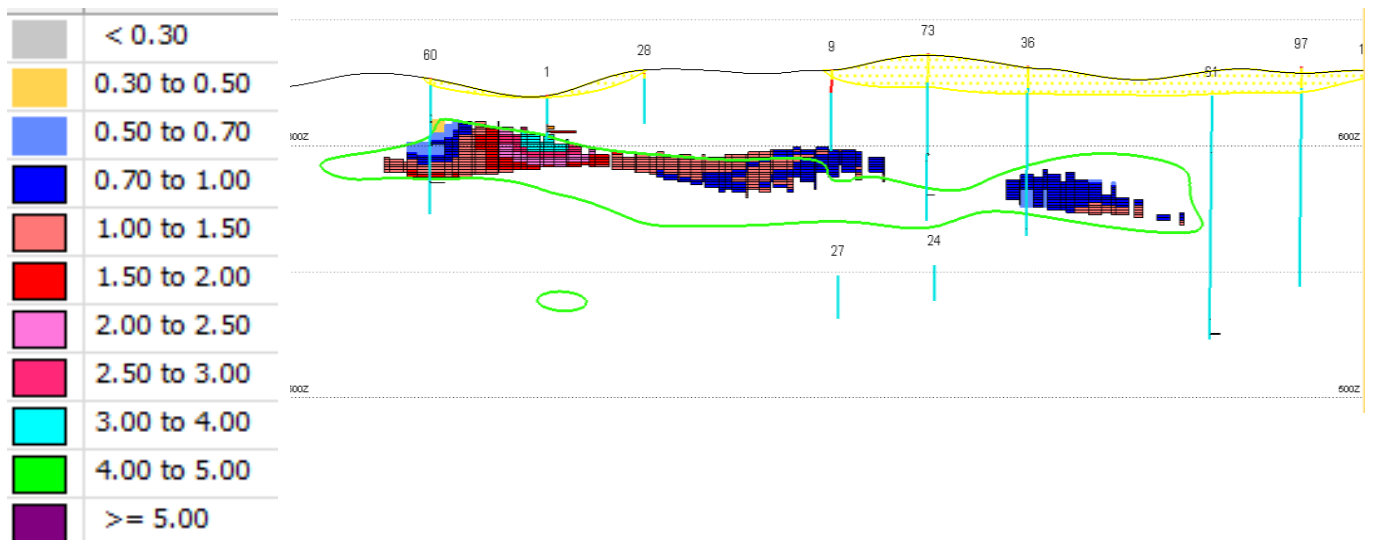

Figure 7 - Longitudinal cut (in green is the mineral area generated by the data base) blocks with different contents of $\mathrm{cu}$.

The copper sulphide mineralization is always located in the gabbro rocks.

The study of the geological model shows that copper content of $0.7-1 \%$ prevails.

Model also creates and a clear reflection of the content of copper inside and outside balance knowing its conditions.

Kcira region shows interest for further research of mineralization, as in gabbro rocks, ultrabasic, and in volcanogenic sedimentary rocks of T1-2(Middle Triassic).

Exploration for copper mineralization should continue mainly in areas where gabbro rocks are dispersed. Searching for new sulphur mineralization should focus on debilitating areas, tectonic cracks with a near longitudinal main direction along gabbro rocks themselves, peridotite gabbro contacts and especially in areas of development of sulphide mineralization, quartz-sulphide and quartz.

\section{References}

Calcagno, P., Chilès, J., Courrioux, G. and Guillen, A., 2008. Geological modeling from field data and geological knowledge: Part I. Modeling method coupling 3D potential-field interpolation and geological rules.

Fallara, F., Legault, M. and Rabeau, O., 2006. 3-D integrated geological modeling in the Abitibi subprovince (Québec, Canada): techniques and applications, Exploration and Mining Geology, 15(2).

Gjoni, S., Tershana, A., 1988. Geological Report with the reserves calculation of copper deposit in the region of Kcira.

Houlding, S.W., 1994. 3D Geoscience Modeling-computer Techniques for Geological Characterization, Springer-Verlag, Berlin, Germany.

Reed, J.P., Volumetric Analysis \& Three-Dimensional Visualization of Industrial Mineral Deposits. Mallet, J.L., 2002. Geomodeling (Applied Geostatistics Series) Oxford University Press, New York.

Sprague, K., Kemp, E., Wong, W., McGaughey, J., Perron, G. and Barrie, T., 2006. Spatial targeting using queries in a 3-D GIS environment with application to mineral exploration Computers and Geosciences, 32(3).

Zanchi, A., Francescac, S., Stefano, Z., Simone, S. and Graziano. G., 2009. 3D reconstruction of complex geological bodies: examples from the Alps Computers and Geosciences, 35. 